\title{
Effect of Various Strains of Mycorrhizae on Growth and Yield of Chilli (Capsicum annuum L.)
}

\author{
S. Shah* and B. K. Singh \\ Department of Horticulture, Institute of Agricultural Sciences, \\ Banaras Hindu University, India \\ *Corresponding author
}

\section{Keywords \\ Mycorrhiza, Warm, Alkaloid capsaicin, Mutualistic \\ Article Info \\ Accepted: \\ 07 November 2019 \\ Available Online: \\ 10 December 2019}

\section{Introduction}

Chilli (Capsicum annuum L.) is an important spice as well as vegetable crop of India. The chilli plants are generally bushy $60-80 \mathrm{~cm}$ high and requires warm and humid climate for growth and dry weather during maturity. Chilli has two important commercial quality parameters, red color due to pigment capsanthin and pungency attributed by capsaicin (Tian et al., 2014). Chilli has medicinal value, besides its richness in vitamin $\mathrm{C}$ due to the fact that an alkaloid capsaicin can be extracted from it. Its per capita consumption in India ranges from 50gms-60gms per day (Prabhavathi et al., 2013). Fresh green chillies contain more vitamin $\mathrm{C}$ than citrus fruits and beside this fresh red Chilli contain more vitamin A than carrots (Osuna Garcia et al., 1998; Than et al., 2008). The symbiotic and mutualistic relationship between the fungus and the roots of higher plants is called mycorrhiza. As evidenced by fossil mycorrhiza found in carbonaceous deposits mycorrhizal fungi appears to have been co-evolved with plants for over 400 million years (Berch et al., 1985). It is exceptional for a plant not to possess a mycorrhizal root system in natural ecosystem. Therefore, it could be said that mycorrhizal association is very common or almost universal phenomenon in plant kingdom (Bagyaraj, 2011). The mycelium of the mycorrhizal fungus can however access these phosphorus sources, and make them available to the plants they colonize. Mycorrhizal 
mycelia can explore a greater volume of soil, providing a larger surface area for absorption as they are very smaller in diameter than the smallest root. The uneasily available soil micronutrients, which are tightly bound to soil for example organic nitrogen, phosphorus, iron etc. can be dissolved by the enzymes released by mycorrhiza, and it clearly signifies that why non mycorrhizal plants require relatively large amount of fertilization.

\section{Materials and Methods}

Experiment was conducted at Vegetable Research Farm, Department of Horticulture, Institute of Agricultural Sciences, Banaras Hindu University, Varanasi during Rabi season 2016-17 with chilli (Capsicum annuum L.) cv. Bhagya Laxmi in a Completely randomized Block Design (CRBD) with nine treatments combination given in (Table 1) and replicated thrice. Temperature ranged from 16.5 to $29^{\circ} \mathrm{C}$ during the trial period. The Bulk density, Soil pH, Organic carbon, Electrical conductivity, Available Nitrogen, Available $\mathrm{P}_{2} \mathrm{O}_{5}$ and Available $\mathrm{K}_{2} \mathrm{O}$ of the soil samples taken from the experimental field were $1.36 \mathrm{~g}$ $\mathrm{cm}^{-3}, 7.12,0.495 \%, 0.45 \mathrm{dSm}^{-1}, 282.4 \mathrm{~kg}$ $\mathrm{ha}^{-1}, 20.16 \mathrm{~kg} \mathrm{ha}$ and $168.0 \mathrm{~kg} \mathrm{ha}^{-1}$ respectively. The seeds of chilli variety Bhagya Laxmi were raised on nursery beds and 30 days old seedlings were transplanted at a spacing of $60 \times 50 \mathrm{~cm}$ in a plot size $3 \times 5 \mathrm{~m}$. The usual agronomic practices were followed as per the endorsed package of practices. To ease the experiment, some plants were randomly selected (five plants were selected for the present investigation) and tagged for recording of observations. Several yield parameters like number of fruits per plant, fruit length, fruit diameter, average fruit weight, fruit yield per plot and fruit yield per hectare were observed and analyzed by using the statistical analysis as described by Panse and Sukhatme (1985). Analysis of variance for all treatment in Complete Randomized Block Design (CRBD) was carried out and ANOVA table was used to test the hypothesis.

\section{Results and Discussion}

The normal growth and development of crop is directly linked to the economic yield of plant. The use of mycorrhiza is a wise option which can prove to be very effective in increasing agricultural production and quality along with good soil health and reduced health hazards arising from excessive use of chemicals. For increasing the agricultural production, mycorrhiza can supplement very efficiently with chemical fertilizers as it increases the availability of nutrients (phosphorus, organic nitrogen, iron, etc.) to the plant. In the experiment, effect of different strains of mycorrhizae were studied like for number of fruits per plant it was found that treatment T2 - Soil application with Myc100 (a $250 \mathrm{~g} / \mathrm{ha} \times 1$ application at 20 DAT (76.43) was highest over T1- Untreated control (57.09) which was similar to (Hadad et al., 2012) on tomato as well as (Gurumurthy et al., 2014) on chilly, (Castillo et al., 2013) on chilean pepper plants and (ManjarrezMartinez et al., 1999) on chilly who reported increased photosynthetic rate and stomatal conductance in mycorrhiza treated plants was the possible reason for the increased number of fruits per plant, for fruit length also treatment T2 - Soil application with Myc100 @ 250 g/ha $\times 1$ application at 20 DAT (10.61 $\mathrm{cm})$ was highest over T1- Untreated control $(8.83 \mathrm{~cm})$ this was because the use of mycorrhizal products significantly increased the length of fruit and this might be due to increased absorption of nutrients such as Phosphorus, Copper, Iron and zinc and the results were in favour with the finding of (Castillo et al., 2013) on the Chilean pepper plants, for fruit diameter the maximum fruit diameter was noticed in treatment T2- Soil application with Myc100@ $250 \mathrm{~g} / \mathrm{ha} \times 1$ application at 20 DAT with value of $1.18 \mathrm{~cm}$ and minimum in treatment. 
Table.1 Effect of various mycorrhizal products on yield parameters of chilli (Capsicum annuum L.) cv. Bhagya Laxmi

\begin{tabular}{|c|c|c|c|c|c|c|c|}
\hline Treatment & Number of & Fruit & Fruit & Average & Fruit yield & Fruit yield & Fruit yield \\
\hline & fruits per & length & diameter & fruit & per plant & per plot & per \\
\hline & plant & $(\mathbf{c m})$ & $(\mathbf{c m})$ & weight (g) & (g) & $(\mathrm{kg})$ & hectare \\
\hline & & & & & & & (q/ha) \\
\hline Untreated control & 57.09 & 8.83 & 0.91 & 2.73 & 156.56 & 7.83 & 62.62 \\
\hline Soil application with Myc100 @ 250 & 76.43 & 10.61 & 1.18 & 3.25 & 211.88 & 10.59 & 84.75 \\
\hline \multicolumn{8}{|l|}{ g/ha $\times 1$ application at 20 DAT } \\
\hline Soil application with Rhizo Myco & 67.71 & 10.10 & 0.99 & 2.84 & 188.81 & 9.44 & 75.53 \\
\hline \multicolumn{8}{|l|}{$100 @ 250 \mathrm{~g} / \mathrm{ha} \times 1$ application at 20} \\
\hline \multicolumn{8}{|l|}{ DAT } \\
\hline Soil application with Rhizo Myxo & 64.63 & 9.10 & 0.95 & 2.65 & 186.99 & 9.35 & 74.80 \\
\hline \multicolumn{8}{|l|}{$100 @ 250 \mathrm{~g} / \mathrm{ha} \times 1$ application at 20} \\
\hline \multicolumn{8}{|l|}{ DAT } \\
\hline Soil application with Bolt Gr. @ 10 & 70.19 & 10.18 & 1.05 & 3.18 & 199.25 & 9.96 & 79.70 \\
\hline \multicolumn{8}{|l|}{$\mathrm{kg} / \mathrm{ha} \times 1$ application at $20 \mathrm{DAT}$} \\
\hline Foliar application with Ratchet @ & 68.95 & 10.14 & 1.05 & 2.93 & 191.17 & 9.56 & 76.47 \\
\hline \multicolumn{8}{|l|}{$300 \mathrm{ml} / \mathrm{ha} \times 1$ application at $30 \mathrm{DAT}$} \\
\hline Foliar application with Ratchet @ & 70.75 & 10.58 & 1.06 & 3.21 & 205.06 & 10.25 & 82.02 \\
\hline \multicolumn{8}{|l|}{$300 \mathrm{ml} / \mathrm{ha} \times 2$ application at 30 and } \\
\hline \multicolumn{8}{|l|}{ 60 DAT } \\
\hline Foliar application with Ratchet @ & 61.71 & 8.91 & 0.93 & 2.64 & 183.55 & 9.18 & 73.42 \\
\hline \multicolumn{8}{|l|}{$450 \mathrm{ml} / \mathrm{ha} \times 1$ application at $30 \mathrm{DAT}$} \\
\hline Foliar application with Ratchet @ & 65.27 & 9.77 & 0.98 & 2.87 & 187.55 & 9.38 & 75.02 \\
\hline \multicolumn{8}{|l|}{$450 \mathrm{ml} / \mathrm{ha} \times 2$ application at 30 and } \\
\hline \multicolumn{8}{|l|}{60 DAT } \\
\hline SE(d) & 2.27 & 0.55 & 0.07 & 0.47 & 5.12 & 0.26 & 2.05 \\
\hline CD at $5 \%$ & 4.8 & 1.16 & 0.15 & 1.00 & 10.86 & 0.54 & 4.34 \\
\hline & & & & & & & \\
\hline
\end{tabular}


T1- Untreated control $(0.91 \mathrm{~cm})$, for average fruit weight treatment T2 - Soil application with Myc100@250 g/ha $\times 1$ application at 20 DAT (3.25 g) was highest over T1- Untreated control $(2.73 \mathrm{~g})$ this may be due to tissue phosphorus which gets increased, resulting in proper formation of nucleic acids and due to cell division average fruit weight might have increased and these results are in agreement with the findings of (Hadad et al., 2012; Alawathugoda, 2014) in tomato and (Castillo et al., 2013) in Chilean pepper, for fruit yield per plant treatment T2- Soil application with Myc100@ $250 \mathrm{~g} / \mathrm{ha} \times 1$ application at 20 DAT (211.88g) was noticed to be superior over treatment T1- Untreated control (156.56 g) and this may be because of the increased nutrient uptake particularly of phosphorus by plant, for fruit yield per plot treatment T2Soil application with Myc100 @ 250 g/ha × 1 application at 20 DAT $(10.59 \mathrm{~kg})$ was noticed to be superior over treatment T1- Untreated control $(7.83 \mathrm{~kg})$ and this may be due to the increased nutrient uptake the yield per plant in experimental plot increased which resulted in increased yield per plot, for fruit yield per hectare also treatment T2- Soil application with Myc100@250 g/ha $\times 1$ application at 20 DAT $(84.75 \mathrm{q} / \mathrm{ha})$ was noticed to be superior over treatment T1- Untreated control (62.62 $\mathrm{q} / \mathrm{ha}$ ) and the significant increase in fruit yield per hectare was due to better nutrient absorption of plants which resulted in better vegetative growth and increased plant biomass. These results are in accordance with the earlier work of (Malik and Kumar 2009; Mujica et al., 2010).

From the present investigation it can be inferred that the best product for increasing all the yield parameters was Myc100 and the optimum concentration for its application is $250 \mathrm{~g} / \mathrm{ha}$ as soil application at $20 \mathrm{DAT}$. In most of the cases, foliar application with Ratchet @ $300 \mathrm{ml} / \mathrm{ha}$ application at 30 and 60 DAT was statistically at par with Soil application of Myc100 @ 250 g/ha 20 DAT.

\section{References}

Alawathugoda, C. J. and Nilanthi, D. (2014). Effects of mycorrhizae as a substitute for inorganic fertilizer on growth and yield of Tomato (Solanum lycopersicum L.) and Soybean (Glycine max L.), and soil microbial activity). Tropical Agricultural Research and Extension, 16(4): 107112.

Bagyaraj, D. J. (2011). Microbial Biotechnology for Sustainable Agriculture, Horticulture and Forestry, New India Publishing Agency, New Delhi.

Berch, S. M., Miller, O. K. Jr and Thiers H. D. (1985). Proceeding $6^{\text {th }}$ North American Conference on Mycorrhizae, Oregon State University Forest Research Laboratory, Corvallis, pp. 189.

Castillo, C., Morales, A., Rubio, R., Barea, J. M. and Borie, F. (2013). Interactions between native arbuscular mycorrhizal fungi and phosphate solubilizing fungi and their effect to improve plant development and fruit production by (Capsicum annuum L.). African Journal of Microbiology Research, 7(26): 3331-3340.

Frank, B. (1885). Ueber die auf Wurzelsymbiose beruhende Ernahrung gewisser Baume durch unterirdische Pilze. Berdent Bot Gessel. 3: 128-45.

Gurumurthy, S. B., Patil, S. V., Vidyavathi, K. B., Lokesh, M. S., Shankrappa, T. H. and Bellakki, M. A. (2014). Agricultural Performance of local isolates of arbuscular mycorrhizal (AM) fungi on growth and yield of chilli (Capsicum annuum L.) grown in black clayey soil. International Journal of Current Microbiology and Applied Sciences, 3(9): 404-408.

Hadad, M. A., Al-Hashmi, H. S. and Mirghani, S. M. (2012). Tomato (Solanum lycopersicum Mill.) growth 
in response to salinity and inoculation with native and introduced strains of mycorrhizal fungi. International Research Journal of Agricultural Science and Soil Science, 2(6): 228233.

Malik, M. F. and Kumar, V. (2009). Influence of INM on growth and yield of tomato. Annals of Horticulture, 2(2): 221-223.

Manjarrez-Martinez, M. J., Ferrera-Cerrato, R. and Gonzalez-Chavez, M. C. (1999). Effect of vermicompost and mycorrhizal fungi on growth and photosynthetic rate of chilli. Terra, 17(1): 9-15.

Mujica Perez, Y., Noval, B., and Dell'Amico, R. (2010). Tomato crop response to the application of two arbuscular mycorrhizal fungi inoculant for different routes of inoculation. Agronomía Tropical (Maracay), 60(4): 381-387.

Osuna-García, J. A., Wall, M. M., and Waddell, C. A. (1998). Endogenous levels of tocopherols and ascorbic acid during fruit ripening of New Mexicantype chilli (Capsicum annuи L.) cultivars. Journal of Agricultural and Food Chemistry, 46(12): 5093-5096.

Prabhavathi, Y., Krishna Kishore, N. T. and Seema (2013). Analysis of supply chain of Spices in India: A case study of Red chillies. International Journal of Scientific and Research Publications, 3(9): 1-4.

Raju, K. V. and Lukrose, C. K. (1991). Trend in area, production and impact of chillies from India. Agricultural Situation in India. 45: 762-772.

Than, P. P., Jeewon, R., Hyde, K. D., Pongsupasamit, S., Mongkolporn, O., and Taylor, P. W. J. (2008). Characterization and pathogenicity of Colletotrichum species associated with anthracnose on chilli (Capsicum spp.) in Thailand. Plant Pathology, 57(3): $562-572$.

Tian, S. L., Lu, B. Y., Gong, Z. H., and Shah, S. N. M. (2014). Effects of drought stress on capsanthin during fruit development and ripening in pepper (Capsicum аппиит L.). Agricultural Water Management, 137: 46-51.

\section{How to cite this article:}

Shah, S. and Singh, B. K. 2019. Effect of Various Strains of Mycorrhizae on Growth and Yield of Chilli (Capsicum annuum L.). Int.J.Curr.Microbiol.App.Sci. 8(12): 488-492.

doi: https://doi.org/10.20546/ijcmas.2019.812.064 